\title{
PSIKOEDUKASI PENTINGNYA PENERIMAAN ORANG TUA DALAM PENANGANAN ANAK BERKEBUTUHAN KHUSUS
}

\author{
Asri Mutiara Putri ${ }^{1}$, Dewi Lutfianawati ${ }^{2}$ \\ ${ }^{1,2}$ Prodi Psikologi Universitas Malahayati \\ Email: asri@malahayati.ac.id
}

\begin{abstract}
ABSTRAK
Menjadi orang tua Anak Berkebutuhan Khusus ( $A B K$ ) merupakan hal yang cukup menantang karena anak memiliki karakter dan perkembangan yang berbeda dengan anak normal pada umumnya. ABK memiliki berbagai macam masalah perilaku, emosi, dan kesulitan akademik yang membuat mereka membutuhkan penanganan dan pengasuhan khusus dibandingkan anak normal lainnya. Salah satu faktor penting dalam memberikan penanganan yang tepat bagi anak adalah penerimaan orang tua terhadap kondisi anak. Orang tua yang menerima kondisi anak sepenuhnya mampu melihat kelebihan dan kekurangan anak sehingga pengasuhan yang diberikan sesuai dengan kebutuhan anak. Namun demikian, studi sebelumnya menemukan bahwa sebagian besar orang tua mengalami kesulitan menerima kondisi anak berkebutuhan khusus. Hal ini membuat penanganan yang diberikan pada anak menjadi tidak optimal, karena kurang bersinergi antara penanganan anak di rumah dengan di sekolah. Oleh karena itu dalam program pengabdian masyarakat ini, dilaksanakan psikoedukasi bagi orang tua ABK. Psikoedukasi ini bertujuan untuk memberikan wawasan terhadap orang tua terkait karakteristik dan permasalahan $A B K$, pentingnya penerimaan dari lingkungan terhadap kondisi $A B K$ dan penanganan yang dapat dilakukan orang tua pada anak di rumah. Kegiatan ini diberikan kepada orang tua ABK di SLB X di Bandar Lampung. Berdasarkan kegiatan yang telah dilakukan dapat disimpulkan kegiatan psikoedukasi ini berhasil meningkatkan pemahaman orang tua akan pentingnya penerimaan terhadap kondisi ABK. Ke depannya, kegiatan seperti ini dapat dilaksanakan pada SLB-SLB lain ataupun dilaksanakan psikoedukasi lanjutan dengan tema-tema yang dibutuhkan oleh orang tua $A B K$ dalam rangka membantu memberikan penanganan yang tepat bagi ABK.
\end{abstract}

Kata Kunci: psikoedukasi, penerimaan orang tua, anak berkebutuhan khusus

\section{ABSTRACT}

Being a parent of Children with Special Needs is quite a challenge because children have different characters and developments from normal children in general. Children with special needs have a variety of behavioral problems, emotions, and academic difficulties that make them require special treatment and care compared to other normal children. One of the important factors in providing appropriate treatment for children is the acceptance of parents to the child's condition. Parents who accept the child's condition are fully able to see the strengths and weaknesses of the child so that the treatment provided is in accordance with the child's needs. However, previous research found that most parents have difficulty accepting the condition of children with special needs. This makes the treatment given to children not optimal, because there is no synergy between handling children at home and 
at school. Therefore, in this community service, psychoeducation was carried out for parents of children with special needs. This psychoeducation aims to provide insight to parents of children with special needs, the importance of acceptance of child's condition and what parents can do for their children at home. This activity was given to parents of children with special needs at SLB $X$ in Bandar Lampung. Based on the activities that have been carried out, it can be said that this psychoeducation activity has succeeded in increasing parents' understanding of the importance of accepting the condition of ABK. Activities like this can be carried out at other special schools or further psychoeducation with different topics needed by parents in helping provide appropriate treatment for children with special needs.

Keywords: Psychoeducation, Parent's Acceptance, Children with Special Needs

\section{PENDAHULUAN}

Kehadiran anak merupakan hal yang sangat dinantikan bagi setiap orang tua. Namun demikian, terkadang anak yang dilahirkan tidak sesuai dengan harapan orang tua, karena memiliki keterbatasan baik secara fisik maupun psikologis. Anak dengan keterbatasan ini biasa disebut dengan anak berkebutuhan khusus. Anak berkebutuhan khusus merupakan anak yang dianggap mempunyai kelainan/penyimpangan dari kondisi rata-rata anak normal umumnya, dalam hal fisik, mental maupun karakteristik perilaku sosialnya (Efendi,2006). Kelainan atau keterbatasan anak berkebutuhan khusus dapat tampil dalam bentuk fisik, seperti hambatan penglihatan dan pendengaran, dalam bentuk emosi, seperti kecemasan berlebihan, dalam bentuk kognitif seperti disabilitas intelektual, serta dalam bentuk sosial seperti hambatan interaksi dan komunikasi. Menurut Kementrian Pemberdayaan Perempuan dan Perlindungan Anak jumlah anak berkebutuhan khusus yang terdata di Indonesia adalah 1,5 juta (Darma \& Rusyidi, 2015). Jumlah tersebut belum benar-benar menggambarkan kondisi yang sesungguhnya karena pendataan biasanya dilakukan pada ABK yang bersekolah. Hal ini meunjukkan jumlah ABK dapat lebih banyak yang terdata.

Anak berkebutuhan khusus membutuhkan penanganan yang berbeda dari anak pada umumnya. Hal ini membuat orang tua harus berperan lebih dalam memberikan pengasuhan yang tepat bagi anak mereka. Untuk memberikan pengasuhan yang tepat, harus diawali dengan penerimaan terhadap kondisi anak berkebutuhan khusus (Faradina, 2016). Orang tua yang menerima kondisi anak sepenuhnya dapat mengenali kelebihan dan kekurangan anak sehingga mampu menentukan penanganan yang terbaik bagi anak. Penerimaan orangtua sangat mempengaruhi perkembangan anakanak yang berkebutuhan khusus di kemudian hari. Sikap orang tua yang tidak dapat menerima kenyataan bahwa memiliki anak berkebutuhan khusus akan sangat buruk dampaknya, karena hal tersebut dapat membuat anak merasa tidak diterima dan diabaikan.

Namun demikian, tidak sedikit orang tua yang justru merasa malu dengan kondisi anak sehingga mereka tidak memberikan perhatian dan penanganan lebih bagi anaknya (Setyaningrum, 2010). Ada pula orang tua yang berusaha 
melakukan kompensasi secara berlebihan untuk menggantikan kekurangan anak. Hal ini membuat anak berkebutuhan khusus terkadang dipaksa menguasai keterampilan tertentu yang justru bukan keterampilan utama yang ia butuhkan dalam menjalani hidup secara mandiri. Berdasarkan penelitian sebelumnya yang dilakukan oleh Anggraini (2013) menemukan bahwa dari 29 orang tua yang memiliki anak berkebutuhan khusus, 17 orang tua $(58,62 \%)$ diantaranya merasa malu, 10 orang tua $(34,48 \%)$ merasa kecewa karena tidak memenuhi apa yang diharapkan. Hal ini menggambarkan masih banyak orang tua anak berkebutuhan khusus yang belum menerima kondisi anak sepenuhnya. Reaksi pertama orangtua ketika anaknya dikatakan bermasalah adalah tidak percaya, shock, sedih, kecewa, merasa bersalah, marah dan menolak (Puspita, 2004). Hal ini merupakan reaksi yang wajar, namun jika tidak ditangani dengan baik akan menimbulkan efek berkepanjangan yang membuat orang tua menjadi semakin tertutup akan kondisi anak, dimana pada akhirnya berdampak buruk terhadap perkembangan anak itu sendiri. Pentingnya penerimaan orang tua terhadap kondisi anak dan masih rendahnya pemahaman orang tua akan hal tersebut mendorong penulis untuk melakukan psikoedukasi kepada orang tua anak berkebutuhan khusus agar orang tua dapat lebih memahami dan meningkatkan penerimaan terhadap kondisi anak berkebutuhan khusus.

\section{MASALAH}

Berdasarkan hasil wawancara dengan pihak sekolah, ditemukan bahwa para orang tua anak berkebutuhan khusus memiliki kecenderungan untuk menganggap sekolah sebagai tempat untuk menitipkan anak mereka dan kurang menunjukkan kepedulian terhadap perkembangan anaknya. Mereka menyerahkan sepenuhnya penanganan anak pada pihak sekolah. Selain itu, terdapat beberapa orang tua yang memiliki harapan dan tuntutan lebih yaitu dengan menuntut anaknya agar memiliki kemampuan yang sama dengan anak normal. Hal-hal ini menunjukkan bahwa orang tua belum dapat menerima sepenuhnya kondisi anak mereka yang berkebutuhan khusus. Melihat besarnya dampak dari penerimaan orang tua terhada perkembangan anak itu sendiri dan masih rendahnya pemahaman orang tua akan hal tersebut, maka dalam program pengabdian masyarakat kali ini diselenggarakan kegiatan psikoedukasi untuk meningkatkan pemahaman orang tua akan pentingnya penerimaan orang tua terhadap anak berkebutuhan khusus serta penanganan yang dapat dilakukan orang tua di rumah untuk membantu anak berkebutuhan khusus.

\section{METODE}

a. Tahap Persiapan

Kegiatan pengabdian masyarakat ini berbentuk psikoedukasi. Sebelum melakukan kegiatan ini, terdapat beberapa persiapan yang perlu dilakukan antara lain persiapan pre dan post test, materi, dan perlengkapan. Tahap persiapan melibatkan pihak SLB sebagai penyedia tempat dan perlengkapan acara, serta komunikasi dengan peserta psikoedukasi yaitu orang tua anak berkebutuhan khusus. 
b. Tahap Pelaksanaan

Kegiatan psikoedukasi dilaksanakan di Aula SLB dengan peserta para orang tua anak berkebutuhan khusus. Acara dibuka oleh kepala sekolah dan dilanjutkan dengan pemberian materi tentang karakteristik anak berkebutuhan khusus, pentingnya penerimaan orang tua serta penanganan anak berkebutuhan khusus di rumah. Sebelum dan setelah kegiatan psikoedukasi diberikan pre dan post test untuk mengetahui keberhasilan dari kegiatan psikoedukasi yang dilakukan.

\section{HASIL DAN PEMBAHASAN}

Kegiatan pengabdian masyarakat ini ditujukan pada orang tua dari siswa berkebutuhan khusus yang bersekolah di SLB X di Bandar Lampung berujmlah 15 orang tua. Kegiatan psikoedukasi secara umum berjalan dengan lancar dan pihak sekolah membantu mempersiapkan tempat dan mengkordinir peserta seminar. Sebelum melakukan kegiatan, peserta diberikan pre test terlebih dahulu kemudian dilanjutkan dengan penyampaian materi yang memaparkan tentang jenis-jenis $A B K$, penerimaan orang tua, dan penanganan anak berkebutuhan khusus di rumah.

a. Anak Berkebutuhan Khusus (ABK)

Anak berkebutuhan khusus adalah "anak-anak yang mengalami penyimpangan, kelainan atau ketunaan dalam segi fisik, mental, emosi dan sosial, atau dari gabungan dari hal-hal tersebut sedemikian rupa sehingga mereka memerlukan pelayanan pendidikan yang khusus yang disesuaikan dengan penyimpangan, kelainan, atau ketunaan mereka (Sumekar, 2009). Anak yang digolongkan sebagai anak berkebutuhan khusus adalah anak-anak yang mengalami keterbelakangan mental, ketidakmampuan belajar atau gangguan atensi, gangguan emosional atau perilaku, hambatan fisik, komunikasi, autisme, traumatic brain injury, hambatan pendengaran, hambatan penglihatan, dan anakanak yang memiliki bakat khusus.

Mangunsong (1998) mengartikan anak dengan kebutuhan khusus adalah anak yang menyimpang dari rata-rata anak normal dalam hal : ciri-ciri mental, kemampuan sensorik, fisik dan neuromuskular, perilaku sosial dan emosional, kemampuan berkomunikasi maupun kombinasi dua atau lebih dari hal-hal di atas; sejauh ia memerlukan modifikasi dari tugastugas sekolah, metode belajar atau pelayanan terkait lainnya, yang ditujukan untuk mengembangkan potensi atau kapasitasnya secara maksimal. Lebih lanjut, menurut Jannah (2004) ABK adalah anak yang dalam proses pertumbuhan atau perkembangan mengalami kelainan atau penyimpangan fisik, mental-intelektual, sosial dan atau emosional dibanding dengan anak-anak lain seusianya, sehingga mereka memerlukan pelayanan pendidikan khusus (Jannah, 2004)

Klasifikasi Anak Berkebutuhan Khusus

Suparno (2007) menyebutkan anak berkebutuhan khusus diklasifikasikan menjadi 3, yaitu anak berkelainan fisik, anak berkelainan mental emosional, anak berkelainan akademik. 


\section{Anak-anak Berkelainan Fisik}

a. Anak Tunanetra

Anak tunanetra adalah anak-anak yang mengalami kelainan atau gangguan fungsi penglihatan, yang dinyatakan dengan tingkat ketajaman penglihatan atau visus sentralis di atas 20/200 dan secara pedagogis membutuhkan layanan pendidikan khusus dalam belajarnya di sekolah.

b. Anak Tunarungu

Tunarungu adalah istilah yang menunjuk pada kondisi ketidakfungsian organ pendengaran atau telinga seorang anak. Kondisi ini menyebabkan mereka memiliki karakteristik yang khas.

c. Anak Tunadaksa

Anak tunadaksa adalah anak-anak yang mengalami kelainan fisik, atau cacat tubuh, yang mencakup kelainan anggota tubuh manapun yang mengalami kelainan anggota gerak dan kelumpuhan yang disebabkan karena kelainan yang ada di syaraf pusat atau otak, disebut sebagai cerebal palsy (CP).

\section{Anak Berkelainan Mental Emosional}

a. Anak Tunagrahita

Tunagrahita adalah seseorang yang memiliki kapasitas intelektual (IQ) di bawah 70 yang disertai dengan ketidakmampuan dalam penyesuaian diri dengan lingkungan sehingga memiliki berbagai permasalahan sosial, untuk itu diperlukan layanan dan perlakuan khusus.

b. Anak Tunalaras

Anak tunalaras adalah anak-anak yang mengalami gangguan perilaku, yang ditunjukkan dalam aktivitas kehidupan sehari-hari, baik di sekolah maupun dalam lingkungan sosialnya. Pada hakikatnya anak-anak tunalaras memiliki kemampuan intelektual yang normal, atau tidak berada di bawah rata-rata. Kelainan lebih banyak terjadi pada perilaku sosialnya.

\section{Anak Berkelainan Akademik}

a. Anak Berbakat

Anak berbakat dalam konteks ini adalah anak-anak yang mengalami kelainan intelektual di atas rata-rata.

b. Anak Berkesulitan Belajar

Anak berkesulitan belajar terdiri dari kesulitan belajar perkembangan (pra akademik) dan kesulitan belajar akademik.

- Kesulitan Belajar Perkembangan (Pra akademik)

a. Gangguan perkembangan motorik (gerak)

Bentuk-bentuk gangguan perkembangan motorik meliputi : motorik kasar (gerakan melimpah, gerakan canggung), motorik halus (gerakan jari jemari), penghayatan tubuh, pemahaman keruangan, dan lateralisasi (arah). 
b. Gangguan perkembangan sensorik (penginderaan)

Bentuk gangguan tersebut mencakup pada proses penglihatan, pendengaran, perabaan, penciuman dan pengecap.

c. Gangguan perkembangan perseptual (pemahaman atau apa yang diinderai) Bentuk-bentuk gangguan ini meliputi : 1) Gangguan dalam persepsi auditoris, berupa kesulitan memahami objek yang didengarkan 2) Gangguan dalam persepsi visual, berupa kesulitan memahami objek yang dilihat. 3) Gangguan dalam persepsi visual motorik, berupa kesulitan memahami objek yang bergerak atau digerakkan. 4) Gangguan memori, berupa ingatan jangka panjang dan pendek. 5) Gangguan dalam pemahaman konsep. 6) Gangguan spasial, berupa pemahaman konsep ruang.

d. Gangguan perkembangan perilaku

Gangguan pada kemampuan menata dan mengendalikan diri yang bersifat internal dari dalam diri anak. Gangguan tersebut terdiri dari : 1) ADD (Attention Deficit Disorder) atau gangguan perhatian 2) ADHD (Attention Deficit Hyperactivity Disorder) atau gangguan perhatian yang disertai hiperaktivitas.

- Kesulitan belajar akademik

Kesulitan belajar akademik terdiri atas disleksia, disgrafia, diskalkulia atau kesulitan berhitung.

\section{b. Penerimaan Orang Tua}

Dalam keluarga, orang tua memegang peranan penting dan bertanggungjawab penuh atas perkembangan anak. Perlakuan yang diberikan oleh orang tua terhadap anaknya akan memberikan dampak bagi anak. Menurut Johnson (1967) penerimaan didefinisikan sebagai pemberian cinta tanpa syarat sehingga penerimaan orang tua terhadap anaknya tercermin melalui adanya perhatian yang kuat, cinta kasih terhadap anak serta sikap penuh kebahagiaan mengasuh anak. Penerimaan orang tua terungkap melalui perhatian pada anak, kepekaan terhadap kepentingan anak, ungkapan kasih sayang dan hubungan yang penuh kebahagiaan dengan anak. Orang tua yang menerima anak ditandai dengn perhatian yang besar dan kasih sayang terhadap anak (Hurlock, 1978). Anak yang diterima orang tua dalam perkembangannya dapat bersosialisasi dengan baik, kooperatif, ramah, loyal, secara emosional stabil, dan gembira.

Aspek-Aspek Penerimaan Orang Tua

Orang tua yang menerima anaknya akan menempatkan anaknya pada posisi penting dalam keluarga dan mengembangkan hubungan emosional yang hangat dengan anak. Porter (dalam Johnson, 1967) mengungkap aspek-aspek penerimaan orang tua terhadap anak yaitu : 
a. Menghargai anak sebagai individu dengan segenap perasaan, mengakui hak-hak anak dan memenuhi kebutuhan untuk mengekspresikan perasaan.

b. Menilai anaknya sebagai diri yang unik sehingga orang tua dapat memelihara keunikan anaknya tanpa batas agar mampu menjadi pribadi yang sehat.

c. Mengenal kebutuhan-kebutuhan anak untuk membedakan dan memisahkan diri dari orang tua dan mencintai individu yang mandiri.

d. Mencintai anak tanpa syarat.

Tahapan Penerimaan Orang tua

Ross (2008), membahas reaksi-reaksi manusia dalam menghadapi "cobaan" dalam hidup. Reaksi tersebut muncul dalam lima tahapan, yaitu:

a. Tahap Denial (menolak kenyataan)

Reaksi pertama yang muncul yaitu rasa tidak percaya saat menerima diagnosa dari seorang ahli, perasaan orang tua selanjutnya akan diliputi kebingungan. Bingung atas arti diagnosa, bingung akan apa yang harus dilakukan, sekaligus bingung mengapa hal ini dapat terjadi pada anak mereka. Ini adalah reaksi yang wajar karena orang tua mengharapkan yang terbaik untuk keturunan mereka. Sulit bagi orang tua untuk menerima kenyataan tentang kondisi anak mereka. Tidak sedikit orang tua yang malu dan menutupi kondisi anak mereka dari lingkungan. Keadaan ini bisa menjadi bertambah buruk, jika keluarga tersebut mengalami tekanan sosial dari lingkungan untuk memberikan keturunan yang "sempurna".

b. Tahap Anger (marah)

Tahapan selanjutnya adalah reaksi marah. Biasanya dilampiaskan kepada beberapa pihak sekaligus, seperti dokter yang memberi diagnosa, menyalahkan diri sendiri atau pasangan hidup. Bisa juga, muncul dalam bentuk menolak untuk mengasuh anak tersebut.

c. Tahap Bargaining (menawar)

Pada tahap ini, orang tua berusaha untuk menghibur diri dengan pernyataan seperti "Mungkin kalau kami menunggu lebih lama lagi, keadaan akan membaik dengan sendirinya".

d. Tahap Depression (depresi)

Tahapan selanjutnya muncul dalam bentuk putus asa, tertekan dan kehilangan harapan. Kadangkala depresi dapat juga menimbulkan rasa bersalah, terutama di pihak ibu, yang khawatir apakah keadaan anak mereka akibat dari kelalaian selama hamil, atau akibat dosa di masa lalu. Ayahpun sering dihinggapi rasa bersalah, karena merasa tidak dapat memberikan keturunan yang sempurna. Putus asa, sebagai bagian dari depresi, akan muncul saat orang tua mulai membayangkan masa depan yang akan dihadapi sang anak. Terutama jika mereka memikirkan siapa yang dapat mengasuh anak mereka, pada saat mereka meninggal. Pada tahap depresi, orang 
tua cenderung murung, menghindar dari lingkungan sosial terdekat, lelah sepanjang waktu dan kehilangan gairah hidup.

e. Tahap Acceptance (pasrah dan menerima kenyataan)

Setelah melalui tahapan sebelumnya, pada tahap ini orang tua mulai menerima kenyataan baik secara emosi maupun intelektual. Orang tua mulai memodifikasi harapan dan persepsi mereka terhadap anak. Orang tua pada tahap ini cenderung mengharapkan yang terbaik sesuai dengan kapasitas dan kemampuan anak mereka.

Karakteristik Orang Tua yang Menerima Anak Berkebutuhan Khusus

a. Orang tua memiliki persepsi yang akurat tentang kemampuan dan keterampilan anak

b. Orangtua mampu mengapresiasi kelemahan dan keterbatasan anak

c. Orang tua tidak dikuasai perasaan bersalah dan mengasihani diri.

d. Orang tua melakukan usaha dalam merawat anak dengan cara yang tepat dan logis, tidak mengharapkan hasil yang instan

e. Orang tua mampu memberikan kasih sayang, tidak menunjukkan penolakan atau over protective, serta tidak mengganggu perhatian atau hubungan dengan anggota keluarga lain.

Dampak Kurangnya Penerimaan Orang Tua terhadap ABK

a. Penanganan yang diberikan tidak sesuai dengan kebutuhan anak

b. Anak sulit berkembang optimal

c. Anak merasa diabaikan dan menjadi beban

d. Anak dapat mengalami gangguan emosi dan perilaku

e. Keharmonisan keluarga terganggu

f. Kesejahteraan psikologis orang tua dan anak tidak tercapai

Hal-hal yang dapat dilakukan orang tua dalam memberikan pengasuhan yang optimal pada anak berkebutuhan khusus

1. Membangun support system

Orang tua dapat mencari orang tua lain yang juga memiliki ABK. Berbagi pengalaman dengan sesama orang tua $A B K$ dapat membantu orang tua menemukan strategi coping yang tepat, menambah sumber informasi dan dukungan, membuat orang tua tidak merasa sendiri, serta mengurangi rasa bersalah dan frustrasi

2. Membuka diri

Orang tua dapat lebih membuka diri terhadap lingkungan dan bantuan professional. Hal ini dapat dilakukan dalam bentuk:

a. Konsultasi dengan psikolog terkait perkembangan dan penanganan perilaku anak

b. Konsultasi dengan dokter terkait kesehatan anak

c. Konsultasi dengan guru atau konselor sekolah tentang bantuan belajar bagi anak

d. Berinteraksi dengan teman dan keluarga lain, untuk lebih memahami kondisi anak

3. Merawat diri

Orang tua juga harus merawat diri sendiri agar dapat merawat anak dengan baik. Orang tua dapat meluangkan waktu 5-10 menit setiap 
hari khusus untuk diri sendiri. Orang tua dapat melakukan hobi atau hal lain yang menyenangkan. Sesekali orang tua juga dapat menitipkan anak pada kerabat agar orang tua memiliki waktu untuk diri sendiri.

4. Menjaga hubungan dengan pasangan

Ibu yang biasanya merupakan pengasuh utama sebaiknya lebih terbuka untuk berkomunikasi dengan ayah sehingga tercipta hubungan yang harmonis dan saling membantu. Hubungan yang harmonis dibutuhkan agar ibu sebagai pengasuh utama tidak merasa sendiri dan penanganan terhadap anak juga dapat diberikan secara lebih maksimal.

5. Menjaga hubungan dengan kakak dan adik

Jika dalam keluarga terdapat anak lain selain anak berkebutuhan khusus, orang tua wajib untuk memberikan pengertian dan pemahaman terhadap kakak atau adik. Selain itu, orang tua juga tetap harus memberi perhatian dan kasih sayang yang setara kepada semua anak, sehingga terjalin hubungan persaudaraan yang baik dan mendukung perkembangan anak berkebutuhan khusus.
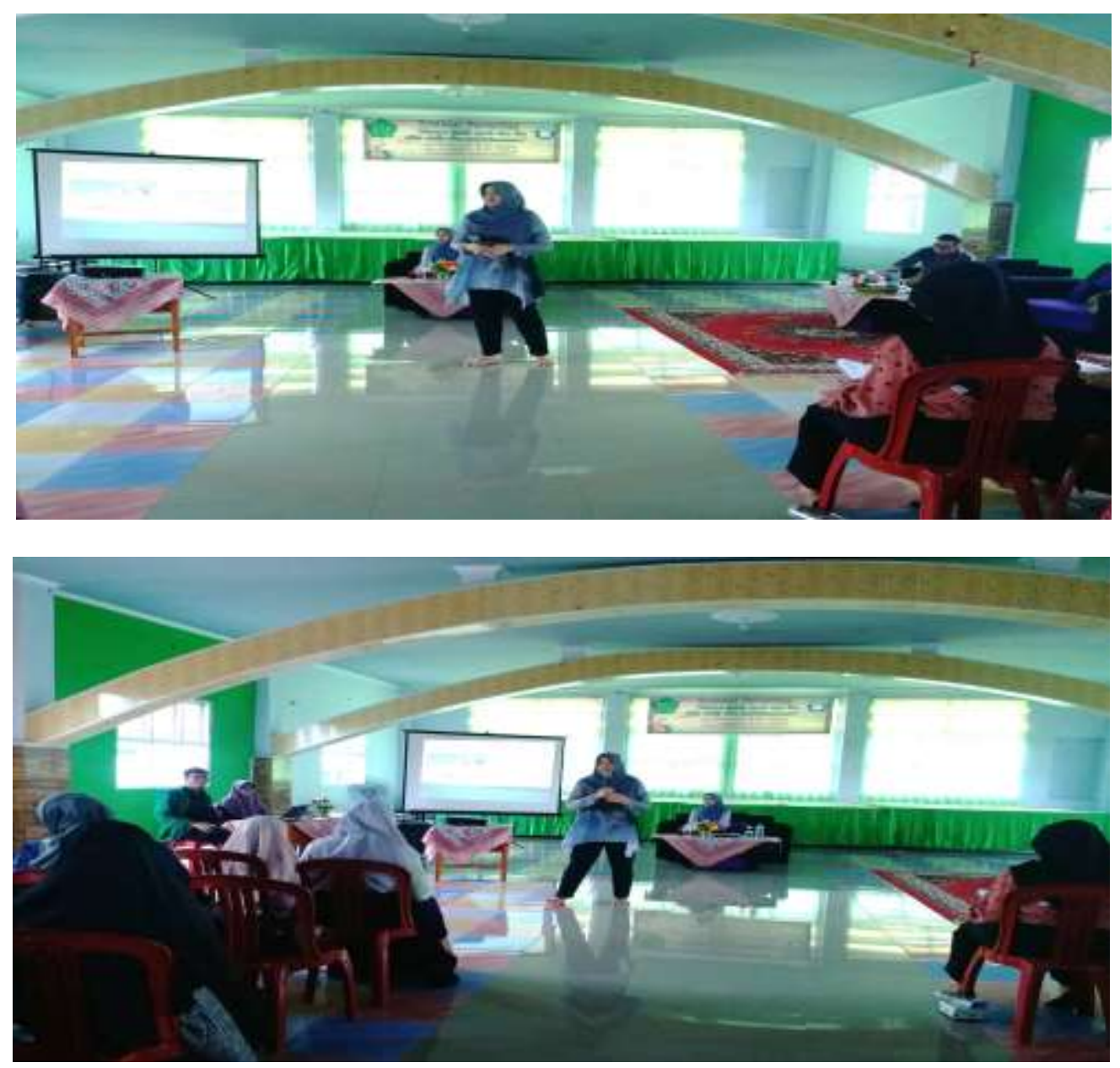


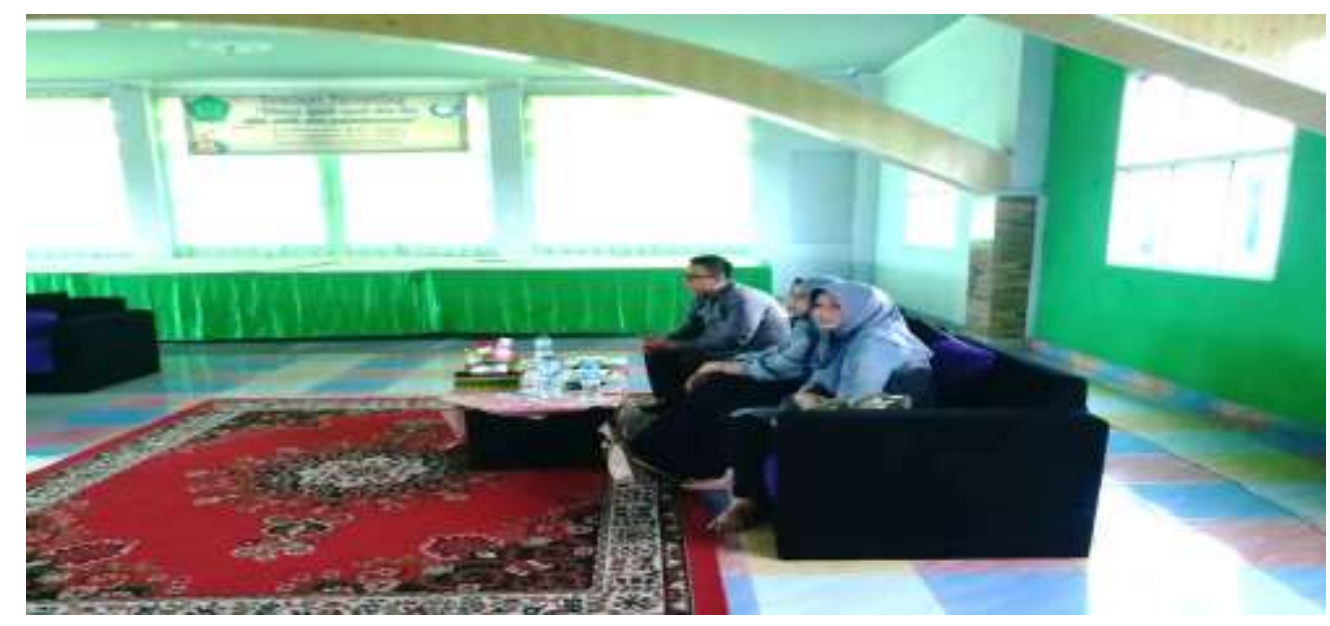

Selama pemberian materi peserta tampak antusias dan memperhatikan isi materi. Di akhir sesi penyampaian materi, moderator memberikan kesempatan kepada peserta untuk mengajukan pertanyaan terkait materi yang di sampaikan. Pada sesi diskusi dan tanya jawab, didapatkan 3 pertanyaan dari orang tua tentang penanganan anak berkebutuhan khusus, seperti peran ayah dalam pengasuhan, perkembangan seksual anak disabilitas intelektual, dan pengenalan minat bakat anak berkebutuhan khusus.

Dalam kegiatan ini, peserta diberikan pre dan post test untuk mengetahui keberhasilan dari psikoedukasi yang dilakukan. Pre dan post test yang diberikan berisi 15 pertanyaan terkait pemahaman orang tua tentang penerimaan terhadap anak berkebutuhan khusus. Berdasarkan hasil analisis yang dilakukan ditemukan terjadi peningkatan pemahaman orang tua akan pentingnya penerimaan terhadap kondisi anak. Hal ini dapat dilihat pada tabel berikut:

Tabel 1

Persentase Pengetahuan Orang Tua Sebelum dan Sesudah Psikoedukasi

\begin{tabular}{lcc}
\hline \multicolumn{1}{c}{ Kategori } & Persentase Pre test & Persentase Post Test \\
\hline Baik & $0 \%$ & $66,67 \%$ \\
\hline Cukup & $60 \%$ & $33,33 \%$ \\
\hline Kurang & $40 \%$ & $0 \%$ \\
\hline
\end{tabular}

Berdasarkan tabel 1 di atas dapat dilihat bahwa pada saat pre test, sebagian besar orang tua memiliki pengetahuan kategori cukup yaitu sebesar $60 \%$ dan tidak ada orang tua yang memiliki pengetahuan baik. Selanjutnya setelah diberikan psikoedukasi, skor post test orang tua cenderung meningkat, yaitu sebagian besar orang tua memiliki pengetahuan yang baik $(66,67 \%)$ dan tidak ada orang tua yang berpengatuhan kurang.

\section{KESIMPULAN}

Kegiatan pengabdian masyarakat ini dilakukan dalam bentuk psikoedukasi yang bertujuan untuk memberikan wawasan dan pemahaman orang tua 
terkait pentingnya penerimaan terhadap kondisi anak berkebutuhan khusus. Penerimaan orang tua sangat dibutuhkan dalam memberikan penanganan yang tepat bagi ABK. Berdasarkan kegiatan yang dilakukan dapat dikatakan psikoedukasi berhasil meningkatkan pengetahuan orang tua tentang pentingnya penerimaan terhadap ABK. Kegiatan psikoedukasi ini dapat dilanjutkan kepada populasi orang tua ABK yang lebih luas dan dapat dilakukan secara bekelanjutan mengingat besarnya peran orang tua dalam penanganan anak berkebutuhan khusus.

\section{DAFTAR PUSTAKA}

Anggraini, R.R. 2013. Persepsi Terhadap Anak Berkebutuhan Khusus. Jurnal Ilmiah Pendidikan Khusus. Volume 1, Januari 2013, 258-264.

Darma, I. P., \& Rusyidi, B. (2015). Pelaksanaan sekolah inklusi di Indonesia. Prosiding Penelitian dan Pengabdian kepada Masyarakat, 2(2).

Efendi, M. (2006). Pengantar psikopedagogik anak berkelainan.

Faradina, N. (2016). Penerimaan diri pada orang tua yang memiliki anak berkebutuhan khusus. Psikoborneo: Jurnal Ilmiah Psikologi, 4(1).

Hurlock, E.B. 1978. Perkembangan Anak Jilid 1, Edisi Keenam. Jakarta: Erlangga.

Jannah, M. 2004. Tumbuh Kembang Anak Usia Dini \& Deteksi Dini pada Anak Berkebutuhan Khusus. Surabaya: Insight Indonesia.

Johnson, R.M. 1967. Child Psychology Behavior dan Development Six Edition. United States of America: John Wiley an Sons, Inc.

Mangunsong, F. 1998. Psikologi dan Pendidikan Anak Luar Biasa. LPSP3. Jakarta: Universitas Indonesia.

Puspita, D. 2004. Peran Keluarga Pada Penanganan Individu Autistic Spectrum Disorder. Diakses pada tanggal 3 April 2013 dari http://puterakembara.org/ rm/peran_ortu.htm.

Ross, E. K. (2008). On Death and Dying : What The Dying Have to Teach Doctors, Nurses, Clergy and Their Own Families. London and New York: Taylor \& France Group.

Setyaningrum, R. 2010. Bantu Anak Berkebutuhan Khusus. Diakses dari http://revisi.joglosemar.co/berita/bantu-anak-berkebutuhankhusus29311.html pada tanggal 20 April 2013

Sumekar, G. 2009. Anak Berkebutuhan Khusus. Padang: UNP Press.

Suparno. 2007. Pendidikan Anak Berkebutuhan Khusus. Jakarta: Dirjend Dikti Depdiknas. 